\title{
Comparative Analysis of Emergency Provisions During A Pandemic
}

\author{
Joyanta Chakraborty \\ Assistant Professor, School of Law, University of Petroleum \& Energy Studies, Dehradun
}

\begin{abstract}
The novel Corona virus is a pandemic that has affected every human being on this planet, either directly by the virus itself, or by the social and economic consequences of the same. Needless to say, this pandemic has also had an effect on the administrations of most, if not all, the nations. This research paper seeks to draw a comparative analysis between the powers of the Executive in India and the United States of America during this pandemic. As we know, India follows a Parliamentary form of governance where the Prime Minister is the Head of the Government and a system of collective leadership is followed, whereas the USA follows a Presidential form of governance where the President is the Head of the State and the principle of individual leadership is followed. A comparative analysis of the two States' powers of the Executive will enable an enhanced comprehension by highlighting important details about pandemic related legislations like the Pandemic and All-Hazards Preparedness Act, 2006 (USA) and the Epidemic Act of India, 1897; and help making abstract ideas more concrete. In this research paper, using the doctrinal method of research, we will analyse the background of the pandemic via medical papers and WHO mandates, and further delve into the executive powers of both, India and the USA during a pandemic by analysing constitutional provisions like that of the $10^{\text {th }}$ Amendment of the Constitution of the USA and the Emergency Provisions under Articles 352 to 360 of the Indian Constitution and different legislations. In conclusion, we shall see that in India, including pandemics as a valid ground to give power to the President to impose a nationwide lockdown, under the National Emergency clause in Article 352 of the Indian Constitution, shall prove to be beneficial.
\end{abstract}

Keywords: Pandemic, parliamentary governance, emergency, constitutional provisions.

\section{Introduction}

The World Health Organization defines a pandemic as "an epidemic occurring worldwide, or over a very wide area, crossing international boundaries and usually affecting a large number of people". Owing to variables such as increasing economic integration, urbanisation, improvements in land utilization, and enhanced degradation of the natural world, it is proposed that the likelihood of disease outbreaks has accelerated over the previous generation. These variables are expected to further escalate and exacerbate. Identification and limiting of emerging outbreaks that might lead to pandemics need significant attention along with the expansion and sustenance of investment to build preparedness and health capacity. Pandemics have many significant impacts, including significant morbidity and mortality rises and relatively greater mortality effects on low- and middle-income countries ( LMICs); economic harm incurred by short-term fiscal shocks and long-term disruptive economic growth shocks; human psychological effects, such as fear-induced job resistance and other public meetings. ${ }^{1}$

Predefined contagion mitigation techniques, if not seriously influenced by the disease outbreak, can also cause huge economic and social disruption. Nations with weakened structures and trends of political uncertainty may, during infectious diseases, face heightened diplomatic tension and anxiety. Pandemic response initiatives have caused incidents of aggression and conflict between regimes and their residents in some circumstances. December 2019 marked the beginning of a novel virus called SARS-CoV-2 or the Corona 
Virus. Phylogenetic research shows that SARS-CoV-2 originated in mammals, presumably bats, and was transferred to other species at a wet market in Wuhan City before crossing into humans. There is some suggestion that pangolin, a form of nocturnal anteater smuggled illegally for its meat, may have been the intermediate vector. This species bears a Corona virus strain that is somewhat similar to SARS-CoV-2, but varies in a key area that specifies the extent of viral infectivity and host. Therefore, it is likely that the virus progressed into humans and then mutated to develop the features that helped it spread so rapidly, via evolution when it affected more people. It resulted in the outbreak of a respiratory illness called COVID-19.Especially worried by the disturbing degree and magnitude of the occurrence and the disturbing degree of neglect, the World Health Organisation proclaimed COVID-19 a disease outbreak on 11 March $2020 .^{2}$

In order to stop the further spread of COVID-19, locating and testing all suspected cases is required in order to confirm cases in an effective manner to further isolate and it is also important to ensure adequate treatment and to quickly classify the latest or similar connections of all such reported cases so which they could be sequestered and recorded by healthcare experts for the 14-day implantation duration of the infection. . Among various methods to contain pandemics, quarantine remains the most common one. Quarantine can be understood as a state or a place of isolation for a being that may have come in contact with a contagious disease(s). This entails travel limitation and, finally, isolation from the majority of the community. The constitutional power for the imposition of lockdown in several nations is in the hands of the governmental machinery.

In the case of the novel Corona virus, it was determined that if enough people participate in quarantine and social distancing, the number of COVID-19 cases would probably remain at a manageable level for the health services. Medical professionals termed this as "flattening the curve," because it would maintain the number of COVID-19 cases below the maximum capacity of medical providers throughout the duration of the outbreak. For this very reason of "flattening the curve", quarantine is a necessary measure during a pandemic like the aforementioned COVID-19. ${ }^{3}$

\section{Findings}

\section{Emergency powers during a pandemic in the} USA.

There are several provisions enshrined in the American Constitution and many other acts that help in the smooth execution and governance in the country during a pandemic. This chapter seeks to study the role and power of the President and Executive during such a non-military emergency in the USA. The total number of National Emergencies in effect by President Donald J. Trump is eight. ${ }^{4}$

Section 201 (a) of the National Emergency Act of 1976, lays down powers and authorizes the President to declare such emergencies at the time of an extraordinary emergency. The act lays down imposition on the procedural powers of the President during emergency. The powers of the executive remain till the pandemic persists after it is proclaimed and issued. The Legislature can even annul a proclamation by passing a resolution by a simple voting majority of both the houses. ${ }^{5}$

Various other acts like the Pandemic and AllHazards Preparedness Act, 2006 (PAHPA), after being amended from Public Health Service, (PHS) exist to facilitate such health emergencies. It has diversified the ambit of the act from before. The PHS had laid down the foundation for Health and Human Services (HHS) to legally declare an emergency if, there exists knowledge about a hazardous infectious disease which risks the health of the entire public by the virtue of section 319 of PHS. PAHPA, on the other hand emphasizes on improving the public health by increasing various funding programs and reauthorizing them to make the nation ready for any biological attack or a pandemic. The purpose of the Pandemic and All-Hazards Preparedness Act is “to improve the Nation's public health and medical preparedness and response capabilities for emergencies, whether deliberate, accidental, or natural."'6

Major Program Areas of the Pandemic and AllHazards Preparedness Act, 2006, include:

Medicinal Expert Jurisdiction for research \& 
development activities (BARDA) and Surgical detection systems;

Emergency Service Feature (ESF) \# 8: Local programmes: health research and emergency management;

Emergency assistance Feature (ESF) \# 8: Emergency Responses and Public Health: Global systems;

- Subsidies;

- People at risk;

- Nationwide plan for health protection (NHSS);

Spacial awareness: monitoring, telehealth and accreditation; and

- Instruction and schooling

They are subject to broad state legislation in the USA, as they often consider a distinct residual force in the states, referred to as "crime force." Particularly industrial activity should be governed for the purposes of health, education, and morality. Alongside the clear economic authority of Congress, this power exists and generally yields not to the statutory grant itself, but only to the legitimate, contradictory exercise of the federal power. $^{8}$

Emergency orders at the federal level, such as the HHS public health emergency declaration under Section 319 of the Public Health Service Act, will encourage and foster medical and public health responses by approving appropriate emergency measures, providing funds to assist intervention or recovery operations, or even waiving fines for failure to comply with appropriate federal laws and regulations during a disaster. Essential federal assets such as the National Disaster Medical System (NDMS) and federal medical stations could also be provided by the federal government to facilitate CSC (Critical standards of Care) responses at the state, provincial, and local levels. States play a vital role in accepting requests from within the community for federal resources; analysing their demands, demanding, obtaining, and allocating these federal resources; and deciding the need for and demanding federal announcements and exceptions. Such practises may also take place in compliance with specific lines of control, in compliance with such state emergency orders, often under the leadership of the Governor or state health department; pre-established federal guidelines and standards may also apply. ${ }^{7}$

\section{Emergency powers during a pandemic in India}

One of the main Central laws in India, to prevent diseases like that of Covid-19, includes the Epidemic Diseases Act, 1897. The aim of this Act is to ensure effective protection of the transmission of hazardous contagious disorders. The purpose of this Act is to guarantee that the spread of dangerous communicable disorders is avoided effectively. This Act allows state and local governments and the state authority to take appropriate or needed measures in order to prevent the continued dissemination of such disorders. ${ }^{9}$

If any of the state governments is satisfied that any part of its territory is threatened with an outbreak of a dangerous illness, it may adopt all appropriate measures, including quarantine, to prevent the outbreak of the said disease. Similarly, if the central government is satisfied that an outbreak of an contagious disease is imminent and that the current provisions of the legislation are insufficient at that time to avert such an outbreak, it must take action and approve regulations authorising the inspection of any ship or vessel leaving or arriving at any port and the detention of any person arriving at any port.Under section 188 of the Indian Penal Code , 1860 , any person found to disobey the regulation issued under the Epidemic Diseases Act, 1897 may be charged with the crime. The defendant is liable, on conviction, to a term of simple imprisonment for one month, a fine, or both, in breach of the clause of the 1897 Act. Notwithstanding everything found in the CrPC, such an offence can be summarily punished at the discretion of the trial magistrate. ${ }^{10}$

Further, for the people that would enter India from foreign land, a health officer is appointed and posted at the port of entry, by the Central government. Only after there is full satisfaction that a ship or aircraft is in full compliance with the health regulations, does the health officer grant pratique, or 'permission to ships to 
have dealings with a particular port, given either after quarantine or on the showing of a clean sheet of health to the vessel or aircraft for landing'. The designated health inspector, which request the airplane, travel medical record consisting of all of the other communities affected by the airplane to be viewed. He should also examine the plane, its occupants, and its personnel, upon his order, and have them undergo physical examinations following delivery. With respect to exchangeable viruses involving a time of containment, such as the Corona Virus, the department shall follow strict measures. In the event that any individual on an airplane is needed to be departed and hospitalised for a duration of time under certain regulations, the officer can transfer him to a facility or go to another unknown place and retain him in confinement.It may restrict the embarkation of any aeroplane of any individual showing illnesses of any quarantined disease when brought to the notice of the health officer. In addition, laws mandate airline workers to record all reported cases that might exhibit severity of the disease requiring isolation, from data gathered. ${ }^{11}$

The Epidemic Diseases Act, 1897, grants the states wide-ranging authority when it comes to state legislation to allow the effective handling of a health problem after the outbreak of an illness. If a state government is concerned that it is or any part of it is endangered by the outbreak of a serious disease and that the ordinary provisions of the law in place at the time are inadequate to resolve the outbreak, it may allow any person to take certain measures and recommend temporary regulations to be followed by the resident; the State Government can also take steps and recommend regulations for the surveillance, vaccination and inoculation of persons travelling by road or train, including their isolation in a hospital, given that such persons are suspected of having been contaminated with some such disease by the inspecting health officer, or that any of these powers have been assigned to the Deputy Commissioners in their respective separate competences. ${ }^{12}$

A state government can also authorise its Deputy Commissioner, by notification in the gazette, to practice all the authority provided in his division under Section 2 of the 1897 Act, which are subject to review by the individual states in their states. Several of these rights are set down in Municipal Corporation Acts that regulate "major urban regions," or Public Health Acts that often offer lockdown or other rights to local commissions or collectors.

\section{Discussion}

\section{Comparative analysis of the emergency powers} during a pandemic in the USA and India:

We saw that both the countries are equipped with several Constitutional provisions, legislations and powers to declare an Emergency during a pandemic. Though, the impact of the ongoing Covid-19 pandemic has not been the same on the aforementioned countries. The USA was among the initial few nations to report a case of the COVID-19 virus, since the Wuhan Corona virus outbreak in China in December of 2019 and a public medical crisis was declared on the $21^{\text {st }}$ of January 2020. In India, the first instance of the virus was reported on the $30^{\text {th }}$ of January 2020 in Kerala, of an individual who had travel history from the most affected region in China, Wuhan. This was followed by the Indian Prime Minister, Narendra Modi ordering a nationwide lockdown for 21 days on 24 March 2020, starting from 25 March 2020. Currently there are 6.54M cases of the virus in the USA and $4.85 \mathrm{M}$ cases of the virus in India. ${ }^{13}$

\section{A) Difference in powers}

The United States of America: Article 2 of the American Constitution essentially lays down that the President of the USA can judge extraordinary occasions and ask both the Houses or either one of them to convene for further discussions and shall recommend his considerations. Further, The National Emergency Act of 1976 lays down imposition on the procedural powers of the President during an emergency. Section 201 (a) of the act authorizes the President to declare such emergencies at the time of an extraordinary emergency. There is a pre-assumption that the President's 'power to regulate' includes whatever power is needed to manage emergencies. There is also a legislation in place to deal with health pandemics like the one we currently face, called the Pandemic and All-Hazards Preparedness Act (PAHPA), Public Law No. 109-417. ${ }^{14}$ 
- India: Unlike the USA, the Indian Constitution does not enable the President to declare a National emergency solely on the basis of "whatever is needed to deal with emergencies" and instead, Article 352 of the Indian Constitution specifies that for the proclamation of a National Emergency, the President must be satisfied that a grave emergency exists where the security of India threatened by the following:

$\varnothing \quad$ War

$\varnothing \quad$ External aggression

$\varnothing \quad$ Armed rebellion

Here, we see that an epidemic or medical emergency is not listed as a criterion for the proclamation of a National Emergency and as the legal maxim, 'expressio unius est exclusio alterius' (the explicit mention of one thing is the exclusion of another) lays down, the exclusion of an epidemic from Art. 352 of the Indian Constitution makes it evident that in the current case of the pandemic of Covid-19, the President does not have the power to declare a National Emergency. ${ }^{15}$

B) Difference in methods of quarantine

The United States of America: The measures to guarantee quarantine in the USA are extreme because of the dread of increase in the rates of the infection. A few states have adopted a more mild strategy, while a few states have indicated the use of measures that can be called severe. Some of the main estimates declared as a part of the lockdown in the USA incorporate the following:

o Non-essential travelling between the States and Mexico stand curbed;

o Schools will stay shut while childcare centres will keep on functioning;

o Boarding schools are to send their students home and state run libraries and museums are to stay shut;

o Businesses where customers are gathered together will be shut down totally;

o Restaurants can keep on operating if they decide to do so and as per the demand of the customers in that area;

o Federal student credits borrowers can apply for a

delay on their instalments for two months with no collected interests; July

o All non-essential businesses and services are to remain closed;

o Pharmacies, medical centres and grocery shops will keep on serving the people;

o Airports will continue to work and trash will be picked up;

o Some states have issued 'stay at home' orders - the people can visit markets and participate in other essentials undertakings;

o Those who can work from home shall do the same;

o Strict measures have been taken to secure the food banks and proceed with their functioning;

o In a few states the government has permitted bars, cafés and businesses to operate.

India: Here, the quarantine measures differ in several ways from the USA. The Lockdown 1.0, as declared by PM Modi had the following features:

o Privately run public transportation companies will pause their services during the lockdown and state run public transport systems will be restricted to 25 people to take into account needs of people working in essential services;

o Businesses have been told to let their work from home;

o Non essential services have been shut;

o Essential businesses like milk supplies, gas, household goods, vegetables and bakers' will keep on functioning;

o Educational institutions will stay shut;

o Public has been kept from social occasions that constitute of people that are in numbers more than five;

o In situations where movement is completely vital, those moving out must maintain the rules of social distancing;

o People have been encouraged to remain at their homes and abstain from leaving until absolutely necessary;

o Restaurants can serve take away meals and 
shopping centres can work just the sections that sell vegetables, home goods and food supplies;

o The essential services like the postal services, the internet and others will continue to serve the public.

\section{Conclusion}

Law is not stagnant; instead it is ever-changing because it involves constant attention, reflection, and evolution. This evolution of law has to take place over time in response to its constantly changing environment. Since laws are never perfect, the lawmakers are to always change or modify existing laws for the benefit of the people being governed by these laws.

In the case of the handling of a pandemic like the Corona virus, we see that the United States of America and its Constitution enables its President to declare a National Emergency on the basis of a preassumption that the power of the President to regulate encompasses whatever power is needed to deal with emergencies. Also, we can say that the regulations of the quarantine differ from state to state on the basis of their own assessment of the severity of the situation in their respective states. This gives the USA space to administer isolation and quarantine on not just a wider basis, but a more logical and assessment based one. Without the power of the President to declare a National Emergency during such crises, the State would render nearly helpless in overcoming them. The legislations to manage specific emergencies like the Pandemic and AllHazards Preparedness Act (PAHPA) then act as helping tool to further overcome these disastrous situations.

When it comes to India, we see that the Emergency provisions in Article 352 of the Constitution does not include a pandemic or an epidemic as a ground for the proclamation of a National Emergency, thus, disabling the President to declare a National Emergency in the case of a health crisis.. India simply just has a legislation, the Epidemic Diseases Act of 1897, for the management of medical crises like a pandemic. This entire paper makes the need to include a 'pandemic' as a valid ground for the proclamation of a National Emergency under Article 352 of the Indian Constitution, extremely evident. Adding to that, looking at the provisions of the USA, we also see the need to let states have some autonomy to vary quarantine orders as per their specific needs. This will act as a blanket provision that will enable the President to be able to declare a National Emergency in situations other than just war, foreign aggression and armed rebellions. Also, letting the states have some degree of autonomy in varying the quarantine regulations within them, in accordance to their own specific situations and needs will provide for a more practical approach to handle such epidemic diseases.

Source of Funding: Self Funding.

Conflict of Interest: The author declares no conflict of interest, financial or otherwise.

\section{Ethical Clearance: None}

\section{References}

1. WHO | The classical definition of a pandemic is not elusive Who.int, https://www.who.int/bulletin/ volumes/89/7/11-088815/en/ (last visited Sep 24, 2020)

2. Can a pandemic 'COVID19' be a ground to declare Health Emergency?- India Legal India Legal, https://www.indialegallive.com/top-news-of-theday/news/can-pandemic-covid19-ground-declarehealth-emergency/ (last visited Sep 24, 2020)

3. Does the Constitution Allow Modi to Declare a National Emergency Over COVID-19? The Wire, https://thewire.in/law/can-an-1897-law-empowerthe-modern-indian-state-to-do-whats-needed-tofight-an-epidemic (last visited Sep 24, 2020)

4. '[COVID-19]: PIL Filed In SC Seeking Imposition Of Financial Emergency (Article 360) Amid Pandemic [Read Petition] Lawstreet.co, https:// lawstreet.co/judiciary/covid19-financialemergency-article360-pandemic/ (last visited Sep 24, 2020)

5. Is COVID-19 or a Declaration of a State of Emergency, a Force Majeure Event? It Depends on Your Contract - Brach Eichler Bracheichler.com, https://www.bracheichler.com/insights/is-covid19-or-a-declaration-of-a-state-of-emergency-aforce-majeure-event-it-depends-on-your-contract/ (last visited Sep 24, 2020)

6. Emergency Powers in the Time of Coronavirus... and Beyond Just Security, https://www.justsecurity. org/70029/emergency-powers-in-the-time-ofcoronaand-beyond/ (last visited Sep 24, 2020) 
7. Opinion: Global hits and misses in dealing Covid-19, takeaways for India - ET Government ETGovernment.com, https://government. economictimes.indiatimes.com/news/governance/ opinion-global-hits-and-misses-in-dealing-covid19-takeaways-for-india/74883374 (last visited Sep 24, 2020)

8. Who.int, https://www.who.int/ihr/IHR_2005 en.pdf (last visited Sep 24, 2020)

9. Considerations for quarantine of contacts of COVID-19 cases Who.int, https://www.who.int/ publications/i/item/considerations-for-quarantineof-individuals-in-the-context-of-containment-forcoronavirus-disease-(covid-19) (last visited Sep 24, 2020)

10. Ethical Issues in Pandemic Planning and Response Ncbi.nlm.nih.gov, https://www.ncbi.nlm.nih.gov/ books/NBK54169/ (last visited Sep 24, 2020)
11. Phe.gov, https://www.phe.gov/Preparedness/legal/ pahpa/Pages/default.aspx (last visited Sep 24, 2020)

12. Govinfo.gov, https://www.govinfo.gov/ (last visited Sep 24, 2020)

13. Home | Department of Legal Affairs, MoL \&J, GoI Legalaffairs.gov.in, http://legalaffairs.gov.in/ (last visited Sep 24, 2020)

14. The 2nd Article of the U.S. Constitution National Constitution Center - The 2nd Article of the U.S. Constitution, https://constitutioncenter.org/ interactive-constitution/article/article-ii (last visited Sep 24, 2020)

15. Weekly update: Human rights violations by Indian Army in Indian Occupied Kashmir (JR 196) Javedrashid.blogspot.com, https://javedrashid. blogspot.com/2019/09/weekly-update-humanrights-violations.html (last visited Sep 24, 2020) 